Vol. 4, No. 03; 2021

ISSN: 2581-4664

\title{
PARTICIPATIVE LEADERSHIP STYLE AND STAFF MOTIVATION IN PRIVATE UNIVERSITIES IN UGANDA: A CASE OF KAMPALA INTERNATIONAL UNIVERSITY
}

\author{
Chrisostom Oketch \\ Lecturer, Kabale University \\ Faculty of Arts and Social Sciences \\ Department of Governance \\ Rosette Ainembabazi \\ Lecturer, Kampala International University \\ College of Humanities and Social Sciences \\ Department of Applied Psychology \\ http://doi.org/10.35409/IJBMER.2021.3256
}

\begin{abstract}
The study examined the effect of participative leadership style on staff motivation in private universities in Uganda, Kampala International University as a case study. Two specific objectives guided the study:(i) to examine the effect of participative leadership style on direction of effort among staff in Kampala International University, and (ii) to establish the effect of participative leadership style on persistence of behavior among staff in Kampala International University. The study hypothesized that (i) "participative leadership style has a significant effect on direction of effort among staff in private universities in Uganda" and (ii) "participative leadership style has a significant effect on persistence of behavior among staff in private universities in Uganda". The study adopted a descriptive correlational design to collect data from a sample of 111 respondents with the aid of a structured questionnaire. Research findings indicated that staff are not consulted in decision-making, their views are not taken into account and as such staff cannot take responsibility for decision outcomes. It was also established that whereas staff persistently exhibit appropriate behavior by working even under hardships, they are not happy with policies in place. The study concluded that participative leadership style is key to directing staff efforts let alone helping them persist in performing behavior necessary for task accomplishment. The study recommends that management of private universities in Uganda should engage staff in the process of decision making through consultations, respect for their views and opinions and above all involvement in formulation of policies that define their day to day work so as to remain motivated.
\end{abstract}

Keyword: Participation, Direction, Effort, Behavior, Motivation

\section{INTRODUCTION}

Leadership style is a mix of various characteristics, traits and behavior that are applied by leaders for controlling the actions of their followers (Mitonga-Monga and Coetzee, 2012). Leadership can also be viewed as a pattern of management associated with controlling the behavior of 


\section{International Journal of Business Management and Economic Review}

Vol. 4, No. 03; 2021

ISSN: 2581-4664

subordinates with a view of harnessing them towards the attainment of specific set goals and objectives. According to Harris et al, (2007) leadership style can be defined as the kind of relationship that is used by a supervisor or superordinate to make their followers accomplish set tasks and assignments for the achievement of a common purpose.

The role of leadership in a university environment is very critical towards the attainment of the institution's goals, purpose, and objectives as highlighted in their vision and mission statements respectively ((Xuand Wang, 2008). Against this background having in place top quality leadership is important for the attainment of the end goals and objectives of the entity putting into consideration that institutions operate in complex and volatile environment characterized by uncertainty, competition that take place within the internal and external environments.

Given that organizations today are faced with a number of management dilemmas ranging from lack of ethics among staff, increasing turnover, and above all financial difficulties, application of the right leadership style becomes paramount in dealing with the above challenges and hence, the application of democratic-also referred to as participative style becomes handy in coordinating the efforts of organizational members towards attainment of set broad objectives which in turn induces staff motivation from the feelings of accomplishment(Harris, et al., 2007).

Tannenbanum and Schmidt (2012) define democratic/ participative leadership style as the leadership in which the decision- making is decentralized and is shared by all the subordinates. Thus, in a participative leadership style, though the possibility of weak execution and likeliness of weak decision- making are evident, it is likely to induce staff motivation given the fact that their views and opinions are adequately put into consideration. Elenkov (2002) established that participative leadership has a positive impact on organizational performance since it allows staff members the ability to make decisions along with sharing their views and opinion with their supervisors. Thus, the leadership style gives praises and criticism are objectively administered and in the process, it creates a sense of responsibilities among staff members.

Relatedly, Bhargavi and Yaseen (2016) in a study on the impact of participative leadership style of performance of organizations established a positive relationship between the two variables and that participation provides provide opportunities to staff members to freely express and implement views and opinions in the process of decision making within the organization in addition to preparing organizational members to take up future leadership positions. Hence this study was conducted to establish the effect of participative leadership style onstaff motivation in private universities in Uganda taking the case of Kampala International University with the objective of recommending the right leadership traits capable of enhancing staff motivation that was measured in terms of direction of effort and persistence of behavior.

\section{Problem Statement}

Participative leadership style is believed to motivate staff members as a result of the involvement and engagement of employees by their line managers in the different aspects that define their key roles in the organization. Such engagement in turn buys the psychological contract and commitment of organizational members as a result of the feeling of responsibility bestowed on to them by management and this will ultimately induce their motivation to work(Elenkov2002). Apparently, leadership behaviors in private universities in Uganda seem to take more of directive style so as to create a work atmosphere of employee engagement as well as a defined chain of command. However, whereas directive leadership styleis appropriate to management of staff in 


\section{International Journal of Business Management and Economic Review}

Vol. 4, No. 03; 2021

ISSN: 2581-4664

private universities in Uganda, it is not sufficient enough to trigger intrinsic and extrinsic motivation among staff as a result of feelings of being pushed. As a result, motivation of staff remains a big concern evidenced from high turnover rates that has a negative bearing on the quality of education given to students. Therefore, if this situation is not addressed, many graduates from private universities will remain unemployed as a result of lacking appropriate skills required by employers. It is against the above background that this study examined the effect of participative leadership style on staff motivation in private universities with a view of developing appropriate management style which ushers in commitment on the part of employees as a result of being involved in decision-making by their supervisors.

\section{General Objective}

The general objective of the study was to examine the effect of participative leadership style on staff motivation in Private Universities in Uganda taking the case of Kampala International University.

\section{Specific Objectives}

1. To examine the effect of participative leadership style on direction of effort among staff in Kampala International University.

2. To establish the effect of participative leadership style on persistence of behavior among staff in Kampala International University.

\section{Questions}

1. What is the effect of participative leadership style on direction of effort among staff in Kampala International University?

2. How does participative leadership style affect persistence of behavior among staff in Kampala International University?

\section{Hypotheses}

1. Participative leadership style has a significant effect on direction of effort among staff in Private Universities in Uganda.

2. Participative leadership style has significant effect on persistence of behavioramong staff in Private Universities in Uganda. 


\section{International Journal of Business Management and Economic Review}

Vol. 4, No. 03; 2021

ISSN: 2581-4664

\section{Conceptual Framework}

Independent Variable

Participative Leadership

- Employee Involvement

- Employee Consultations

- Accommodating employee concerns
Dependent Variable

Staff Motivation

\section{Effort}

- Direction of Effort

\section{Behavior}

- Persistence of Behavior

Figure 1: Conceptual Framework indicating the interplay between Participative Leadership Style and Staff Motivation

Source: Researcher developed using ideas of House (1971) and Fiedler (1967).

Figure 1 depicts the perceived interplay between participative leadership style and staff motivation in private universities in Uganda. The independent variable is measured in terms of (employee involvement, employee consultations, and accommodating employee concerns) conceptualized to have a significant effect on staff motivation measured in terms of (direction of effort and persistence of behavior). From the model above, the study deduces that the ability of mangers to put employee input in their day to day decision making will have a significant effect on their motivation to work and the reverse is evident.

\section{LITERATURE REVIEW}

\section{Participative leadership style and staff motivation}

Participative leadership takes a process of joint decision-making or at least shared influence in decision-making by a leader and his or her subordinates (Koopman and Wierdsma, 1998). Participative leadership further involves consulting with subordinates and taking account of their opinions and suggestions when making decisions (Iranejad, 2008). Thus, it is a process whereby the leader has a master-master relationship with group members. The leader uses a consultative approach to encourage group participation in decision making and the approach is democratic by virtue of taking decisions whilst engaging organizational members.

Gaertner (2000) argues that more flexible and participatory management styles can strongly and positively enhance organizational commitment. Organizations need to ensure that leadership strategies are aimed at improving employee commitment rather than compliance as with autocratic leadership style.

Participative leadership is consulting with subordinates and evaluating their opinions and suggestions before making the final decision (Mullins, 2005). The main vehicle for the success 


\section{International Journal of Business Management and Economic Review}

Vol. 4, No. 03; 2021

ISSN: 2581-4664

of participative leaders is their use of participative decision making (PDM) which allows employees across all levels in the organization to be involved in the final decision. Various studies suggest that participative decision-making (PDM) offers a variety of potential benefits such as increasing employee's job satisfaction and increasing the level of innovation in the organizations (Somech, 2002); increasing the quality of the decisions made (Scully, Kirkpatrick, and Locke, 1995); contributing to the quality of employee's work life (Somech, 2002); increasing employees' motivation (Locke and Latham, 1990); and increasing the level of employee's commitment (Armenakis, Harris, \&Mossholder, 1993).

$\mathrm{Wu}(2006)$ in a study "The effect of leadership styles of managers on organizational commitment of the employees" evaluated four situational leadership styles (directive, participative, selling /persuasion \&delegative). The results showed that the managers using democratic leadership style, the degree of their employee's commitment is significantly higher than those led by authoritative and noninterference leadership styles. Thus, employees led by a democratic leadership style have a higher degree of value, retention commitments and overall effort to improve their performance than those led by an authoritative leadership style.

According to Somech (2002), motivated employees usually believe that they are doing something worthwhile and they believe that their participation is valued. As such, participative leadership style focuses on the intrinsic motivation of followers by enriching subordinates jobs through autonomy, variety and empowerment. Moreover, when employees participate in democratic decision making, they realize that their ideas are respected and considered by higher supervisors; they feel connected with the organization as if they are important parts in the company and try to reach maximum performance. Somech (2002) further observes that when implementing participative decision-making strategies in the workplace scenario, huge benefits are offered for both leaders and employees. It Increases employee's motivation, increases the level of innovation in organizations, increases the quality of decision making, contributes to the quality of employee's work life, and increases the level of employee's commitment.

Khuong and Hoang (2015) also observed that because participative leadership impacts on employees' motivation, a leader can follow some suggestions to make sure that everybody has a say and that decisions are made as well as gain more benefits from this leadership style. First of all, a leader should create and improve the morale of a workplace that help employees feel engaged with the company whenever they contribute ideas, or business decisions, and activities. When employees feel like their role is less submissive and restricted, they have less of a tendency to withdraw and focus more on task completion. In addition, they are more opened to share views, discuss perspectives on those ideas freely before making decisions.

Nemaei (2012) conducted a study on the impact of participative leadership on employee's motivation, job satisfaction and innovation and found out that the level of employee's motivation, job satisfaction and innovation is higher when participative leadership is used. Hence this leadership style is better than transformational leadership when the regarded factors are in concern. His study further revealed that the main problem with transformational leaders is that they don't use democratic decision making. Based on employee suggestions, leaders should listen to all employees' ideas and act upon them. Thus, the anti-democratic nature of transformational leadership frustrates followers and negatively impact employee's innovation, motivation and job satisfaction.

Babak(2012) established that when democratic leadership style is used by allowing everyone to 


\section{International Journal of Business Management and Economic Review}

Vol. 4, No. 03; 2021

ISSN: 2581-4664

get a say in making the decision, the final decision has support from the majority of employees. Because the leader is transferring the power to the followers, this leadership style can increase the level of trust, motivation, innovation and job satisfaction in the organization. However, the style can be time consuming and can be difficult to get the majority onboard. Moreover if the technique is over used it can have negative effect on the organization so it is critical for the leader to know when to intervene.

Participative Leadership which involves the managing of group meetings influences commitment and conformity, and assists in conflict and communication issues. (Yukl, 2002). Accordingly employees usually believe that they are doing something worthwhile and they believe that their participation is valued (group members depend on them and listen to their ideas). Thus, participative leadership style focuses on the intrinsic motivation of followers by enriching subordinates jobs through autonomy, variety and empowerment. Moreover, when employees participate in democratic decision making, they realize that their ideas are respected and considered by higher supervisors; they feel connected with the organization as if they are important parts in the company and try to reach maximum performance.

Heneman and Gresham (1999) argue that democratic leadership style promotes the sharing of responsibility, the exercise of delegation and continual consultation. In it, effectively delegate tasks to subordinates and give them full control and responsibility for those tasks, and encourage others to become good leaders. Managers also get involved in employee potential leadership and development leading to employee commitment towards meeting departmental goals, and performing to meet deadlines.

Kirega (2006) evaluated worker's views of their senior and top leadership team and found that participative leadership style focuses on using the skills, experience, and ideas of others. However, though leaders and managers involve others in decision making, final decision making power rests in the leader's hand. However, they will not make major decision without first getting the input from those that will be affected, provide proper recognition, and delegate responsibilities. This in turn boosts employee morale and commitment leading to their motivation and commitment to the organization.

Kanter (1999) suggests that, in order to build commitment to change, managers should allow employees to participate; provide a clear picture or vision for the future; share information; demonstrate commitment to the change; tell employees exactly what is expected of them; and offer positive reinforcement. This kind of information sharing helps alleviate the feelings of uncertainty in the minds of the employees. They get more clarity about their roles and the future direction of the organization and in this motivates them towards organizational goal accomplishment.

Zeffanne (2003) opined that the answer to the question of employee commitment, morale, loyalty and attachment may consist not only in providing motivators, but also to remove demotivators such as styles of management not suited to their context and to contemporary employee aspirations. Thus, a leadership or management style that encourages employee involvement can help to satisfy employee's desire for empowerment and demand for a commitment to organizational goals.

Despite of the above positive arguments in favor of participative leadership style, Yammarino and Naughton (1992) noted that the time and energy spent in calling meetings, soliciting ideas and training participants may affect deadlines. The involvement of subordinates may be 


\section{International Journal of Business Management and Economic Review}

Vol. 4, No. 03; 2021

ISSN: 2581-4664

perceived as a loss or sharing of power, thus creating resentment at the leadership level. This may affect the performance of leaders which in turn, may affect subordinate performance. Some workers may not want to be involved in the decision-making aspects of jobs. When the leader is distrusted or when a poor labour relations climate is present, subordinates may see their participation as "doing management's job". When governments attempt to involve the community in education reform, health care, economic and social development, it may be perceived as "down loading", especially if these activities are undertaken in conjunction with other programs and economic cutbacks. It appears that broad-based participation in short-term projects may not be as advantageous as implementing a participation model among a group of employees that will be part of the same team for an extended period, and have become very knowledgeable and proficient at their job. Inability to recognize this can lead to a lack of confidence in the process, the leaders, and create resistance to participation.

\section{METHODOLOGY}

The study used a descriptive correlational design in collecting data from respondents who consisted of academic and administrative staff. The design enabled the investigation of contemporary phenomena in the area of management (leadership styles and staff motivation) thereby enabling the respondents to describe real phenomenon of the problem under investigation. Besides, the design was instrumental in aiding the testing of the effect of the independent variable on to the dependent variables.

The study population was 173 , from where a sample size of 120 respondents were chosen using Slovens Formula to take part in the study through answering a questionnaire. From the 120 questionnaires administered to the respondents, One Hundred Eleven (111) were retrieved, edited, coded and analyzed by the researcher. The response rate stood at $92.5 \%$ and it was considered good enough for the study since it was way above a response rate of $50 \%$ recommended by TomaskovivDevey, et al., (1994) for social research.

In ensuring validity and reliability, the research instrument was subjected to review by content experts who rated them for wording, relevancy, and omissions, from where a content validity index of $(\mathrm{CVI}=.814 \& .877)$ made the instrument to be declared reasonably content validity according to Amin(2005). Reliability was ensured through pre-testing and Cronbach Alpha Reliability Statistics of (.876 \& .887) was computed and hence rendering the instrument reliable and consistent according to Cronbachand Shevelson(2004) as illustrated on Table 1 below.

Table 1: showing validity and reliability test

\begin{tabular}{|l|l|l|l|}
\hline Factor & $\begin{array}{l}\text { Number of } \\
\text { Items }\end{array}$ & Cronbach Alpha & Content Validity Index \\
\hline Staff motivation & 16 & 0.876 & 0.814 \\
\hline Participative leadership style & 05 & 0.887 & 0.877 \\
\hline
\end{tabular}

Data obtained from questionnaires was edited, coded and responses entered into computer using Statistical Program for Social Sciences (SPSS) software from where frequencies, percentages, means, correlations and regression analysis tests were computed as presented below. 
International Journal of Business Management and Economic Review

Vol. 4, No. 03; 2021

ISSN: 2581-4664

\section{RESULTS}

Objective One: Effect of participative leadership style on direction of effort among staff in Kampala International University

The first objective of the study examined the effect of participative leadership style on staff direction of effort in Kampala International University. The objective was measured using Five (5) items and respondents were requested to rate their opinion on a likert scale ranging from $1=$ Strongly Disagree; $2=$ Disagree; $3=$ Neutral; $4=$ Agree; to $5=$ Strongly Agree. Their responses were edited, coded and analyzed as summarized in Table 2 below:

Table 2: Descriptive results showing the effect of participative leadership style on direction of effort among staff inKampala International University.

\begin{tabular}{|l|l|l|l|l|l|l|l|}
\hline Participative leadership style & $\mathbf{( \% )}$ & $\mathbf{( \% )}$ & $\mathbf{( \% )}$ & $\mathbf{( \% )}$ & $\mathbf{( \% )}$ & & \\
\hline Statements & $\mathbf{S D}$ & $\mathbf{D}$ & $\mathbf{N}$ & $\mathbf{A}$ & $\mathbf{S A}$ & $\mathbf{M e a n}$ & $\mathbf{S t d D e v}$ \\
\hline $\begin{array}{l}\text { You are consulted in decision-making and this makes } \\
\text { you direct efforts where needed in the organization }\end{array}$ & 16.2 & 20.7 & 32.4 & 24.3 & 6.3 & 2.837 & 1.156 \\
\hline $\begin{array}{l}\text { Managers respect your views and opinionsat work } \\
\text { which induces more energy to work }\end{array}$ & 13.5 & 25.2 & 22.5 & 27 & 11.7 & 2.981 & 1.243 \\
\hline $\begin{array}{l}\text { You take responsibility for outcomes of a decision and } \\
\text { this makes you add more energy to work }\end{array}$ & 7.2 & 18 & 26.1 & 38.7 & 9.9 & 3.261 & 1.093 \\
\hline $\begin{array}{l}\text { You express your feelings freely with your supervisor } \\
\text { which enhances more effort you put at work }\end{array}$ & 3.6 & 12.6 & 14.4 & 51.4 & 18 & 3.675 & 1.028 \\
\hline $\begin{array}{l}\text { You get solutions/answers to your queries from the } \\
\text { HOD/ supervisor and this makes you put extra effort } \\
\text { at work }\end{array}$ & 7.2 & 6.3 & 18 & 46.8 & 21.6 & 3.693 & 1.102 \\
\hline
\end{tabular}

Source: Primary Data, 2018

Table 2 reveal that majority of the respondents remained neutral/ undecided about being involved in the day to day affairs of their work. For instance they remained undecided about being consulted in decision making (Mean $=2.837$ ); managers respect their views and opinions at work (Mean $=2.981$ ) and taking responsibility for outcome of decisions (Mean = 3.261). In addition, they agreed about expressing their feelings freely with their supervisors (Mean =3.675), and getting solutions/ answers to their queries from supervisors (Mean = 3.693). These findings indicate that whereas staff are in position to freely express their feelings to supervisors and always get solutions/ answers to their queries, management does not adequately involve staff in decision making, they rarely take their views and opinion at work and as a result, employees cannot take responsibility for such decision outcomes. All the above point to the fact that employee participation and involvement is still at its lowest in the university. 


\section{International Journal of Business Management and Economic Review}

Vol. 4, No. 03; 2021

ISSN: 2581-4664

\section{Hypothesis One Testing}

From the first objective of this study, it was hypothesized that participative leadership style has a significant effect on direction of effort among staff in private universities in Uganda. To test the hypothesis, a correlation analysis was computed using Pearson's correlation coefficient and significance statistics and below are results in Table 3.

Table 3: Pearson Correlation results between participative leadership style and direction of effort among staff in private universities in Uganda

(Level of significance $=\mathbf{0 . 0 5}$ )

\begin{tabular}{|c|c|c|c|}
\hline & & $\begin{array}{l}\text { Participative } \\
\text { leadership style }\end{array}$ & $\begin{array}{l}\text { Direction of } \\
\text { effort }\end{array}$ \\
\hline \multirow{3}{*}{$\begin{array}{l}\text { 1. Participative leadership } \\
\text { style }\end{array}$} & Pearson Correlation & 1 & $.211^{*}$ \\
\hline & Sig. (2-tailed) & & .026 \\
\hline & $\mathrm{N}$ & 111 & 111 \\
\hline \multirow[t]{3}{*}{ 2. Direction of effort } & Pearson Correlation & $.211^{*}$ & 1 \\
\hline & Sig. (2-tailed) & .026 & \\
\hline & $\mathrm{N}$ & 111 & 111 \\
\hline
\end{tabular}

*. Correlation is significant at the 0.05 level (2-tailed).p $\leq 0.05$

Source: Primary data, 2018

Results in Table 3 above indicate a positive and significant effect between participativeleadership style and direction of effort among staff $(\mathrm{r}=.211 ; \mathrm{p}=.026)$ at the 0.05 significance level. Thus, direction of effort among staff in private universities in Uganda is influenced by the leader's ability to involve and engage staff in taking key decisions that affect the day to day running of the organization.

\section{Regression Analysis}

So as to establish the extent to which participative leadership style affects direction of effort among staff in private universities in Uganda, aregression test was computed whose results are below presented in Table 4.

Table 4: Regression Analysis results between participative leadership style and direction of effort among staff in private universities in Uganda

\begin{tabular}{|l|l|l|l|l|}
\hline Model & R & R Square & $\begin{array}{l}\text { Adjusted } \\
\text { Square }\end{array}$ & $\begin{array}{l}\text { Std. Error of } \\
\text { the Estimate }\end{array}$ \\
\hline 1 & $.211^{\mathrm{a}}$ & .045 & .036 & .46616 \\
\hline
\end{tabular}

a.Predictors: (Constant), Participative Leadership Style

b. Dependent Variable: Direction of effort among staff

The Coefficient of determination (Adjusted R Square) value is .036 indicating that participative 


\section{International Journal of Business Management and Economic Review}

Vol. 4, No. 03; 2021

ISSN: 2581-4664

leadership style explains $36 \%$ variation in direction of effort among staff in private universities in Uganda.

The researcher further carried out a regression Coefficient statistics on participative leadership style and direction of effort among staff in private universities in Uganda as presented in Table 5 below.

Table 5: Regression Analysis Coefficient on participative leadership and direction of effort among staffin private universities in Uganda

\begin{tabular}{|c|c|c|c|c|c|}
\hline \multirow[b]{2}{*}{ Model } & \multicolumn{2}{|c|}{$\begin{array}{l}\text { Unstandardized } \\
\text { Coefficients }\end{array}$} & \multirow{2}{*}{ 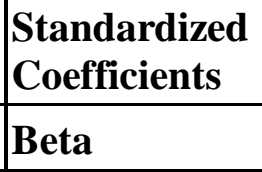 } & \multirow[b]{2}{*}{$\mathbf{t}$} & \multirow[b]{2}{*}{ Sig. } \\
\hline & B & Std. Error & & & \\
\hline $\begin{array}{l}1 \text { (Constant) } \\
\text { Participative leadership }\end{array}$ & $\begin{array}{l}3.447 \\
.123\end{array}$ & $\begin{array}{l}.185 \\
.055\end{array}$ & .211 & $\begin{array}{l}18.629 \\
2.257\end{array}$ & $\begin{array}{l}.000 \\
.026\end{array}$ \\
\hline
\end{tabular}

a. Dependent Variable: direction of effort among staff

Source: Primary Data, 2018

Table 5 indicate a positive and significant effect between participative leadership style and direction of effort among staff in private universities in Uganda $(\mathrm{t}=18.629 ;$ Sig. $=.000)$. Table 5 further indicate that participative leadership style is a good predictor variable of direction of effort among staff in private universities in Uganda $(\beta=.211$; Sig. $=.026)$ implying that for every increase in value of participative leadership style by .211, direction of effort among staff in private universities in Uganda increases by one unit and vice versa. The implication of all the above is that participative leadership style significantly affect direction of effort among staff. Hence, alternative hypothesis ofexistence of significant effect between participative leadership style and direction of effort among staff in private universities in Uganda is accepted.

Objective Two: Effect of participative leadership style on persistence of behavior among staff in Kampala International University

The second objective of the study examined the effect of participative leadership style on persistence of behavior among staff in Kampala International University. The objective was measured using Seven (7) items and respondents were requested to rate their opinion on a likert scale ranging from 1= Strongly Disagree; 2= Disagree; 3= Neutral; 4= Agree; to 5= Strongly Agree. Their responses were edited, coded and analyzed as summarized in Table 6 below:

Table 6:Descriptive results showing the effect of participative leadership style on persistence of behavior among staff inKampala International University

\begin{tabular}{|l|l|l|l|l|l|l|l|}
\hline Persistence of behavior among staff & $\mathbf{( \% )}$ & $\mathbf{( \% )}$ & $\mathbf{( \% )}$ & $\mathbf{( \% )}$ & $\mathbf{( \% )}$ & & \\
\hline Statements & SD & $\mathbf{D}$ & $\mathbf{N}$ & $\mathbf{A}$ & SA & Mean & Std Dev. \\
\hline You continue to work no matter what happens & 3.6 & 2.7 & 11.7 & 52.3 & 29.7 & 4.018 & 0.924 \\
\hline
\end{tabular}




\section{International Journal of Business Management and Economic Review}

Vol. 4, No. 03; 2021

ISSN: 2581-4664

\begin{tabular}{|l|l|l|l|l|l|l|l|}
\hline $\begin{array}{l}\text { You always persevere during times of hardships at } \\
\text { work }\end{array}$ & 00 & 2.7 & 4.5 & 57.7 & 35.1 & 4.252 & 0.666 \\
\hline You like your work & .9 & 4.5 & 9.9 & 32.4 & 52.3 & 4.306 & 0.892 \\
\hline You are happy with work policies & 7.2 & 35.1 & 29.7 & 18.9 & 9.0 & 2.873 & 1.088 \\
\hline You work to your best ability & 4.5 & 3.6 & 4.5 & 37.8 & 49.5 & 4.243 & 1.019 \\
\hline You devote all your time to your work & 1.8 & 5.4 & 16.2 & 42.3 & 34.2 & 4.018 & 0.943 \\
\hline $\begin{array}{l}\text { You are able to strike a balance between work and } \\
\text { family obligations }\end{array}$ & 7.2 & 27.9 & 45 & 19.8 & 3.774 & 0.849 \\
\hline
\end{tabular}

Source: Primary Data, 2018

Table 6 presents respondents rating of persistence of behavior as a measure of staff motivation in Kampala International University. Majority of the of the respondents agreed that they continue to work no matter what happens ( $($ Mean $=4.018)$, they persevere during times of hardships at work $($ Mean $=4.252)$, they like their work $($ Mean $=4.306)$, they work to the best of their ability (4.243), they devote all their time at work (Mean $=4.018$ ), they are able to strike a work-lifebalance $($ Mean $=3.774)$. however they indicated that they are not happy with work policies (Mean $=2.873)$. These findings give the indication that staff of Kampala International University are able to maintain appropriate behavior at work that is capable of helping them achieve what is expected of them by management despite of working in unconducive environments where the policies are not friendly.

\section{Hypothesis Two Testing}

From the second objective of the study, it was hypothesized that participative leadership style has a significant effect on persistence of behavior among staff in private universities in Uganda. To test the hypothesis, a correlation analysis was computed using Pearson's correlation coefficient and significance statistics and below are results in Table 7.

Table 7: Pearson Correlation results between participative leadership style and persistence of behavior among staff in private universities in Uganda

(Level of significance $=\mathbf{0 . 0 5}$ )

\begin{tabular}{|l|l|l|l|}
\hline & & $\begin{array}{l}\text { Participative } \\
\text { leadership style }\end{array}$ & $\begin{array}{l}\text { Persistence of } \\
\text { behaviour }\end{array}$ \\
\hline \multirow{3}{*}{\begin{tabular}{c} 
1. $\begin{array}{c}\text { Participative leadership } \\
\text { style }\end{array}$ \\
\cline { 2 - 4 }
\end{tabular}} & Pearson Correlation & 1 & $.452^{*}$ \\
\cline { 2 - 4 } & Sig. (2-tailed) & & .034 \\
\cline { 2 - 4 } & $\mathrm{N}$ & 111 & 111 \\
\hline \multirow{2}{*}{ 2. Persistence of behaviour } & Pearson Correlation & $.452^{*}$ & 1 \\
\cline { 2 - 4 } & Sig. (2-tailed) & .034 & \\
\cline { 2 - 4 } & $\mathrm{N}$ & 111 & 111 \\
\hline
\end{tabular}

*. Correlation is significant at the 0.05 level (2-tailed). $\mathrm{p} \leq 0.05$

Source: Primary data, 2018

Results in Table 7 above indicate a positive and significant effect between participative leadership style and persistence of behavior among staff in private universities in Uganda $(\mathrm{r}=$ $.452 ; \mathrm{p}=.034)$ at the 0.05 significance level. Thus, persistence of behavior among staff in private 


\section{International Journal of Business Management and Economic Review}

Vol. 4, No. 03; 2021

ISSN: 2581-4664

universities in Uganda is influenced by the leader's ability to involve them in making policies that will guide how they will continue exhibiting behavior deemed appropriate for task accomplishment.

\section{Regression Analysis}

So as to establish the extent to which participative leadership style affects persistence of behavior among staff in private universities in Uganda, a regression test was computed whose results are below presented in Table 8 .

Table 8: Regression Analysis results between participative leadership style and persistence of behavior among staff in private universities in Uganda

\begin{tabular}{|c|c|c|c|c|}
\hline \multicolumn{5}{|c|}{ Model Summary } \\
\hline Model & $\mathbf{R}$ & R Square & $\begin{array}{ll}\text { Adjusted } & \text { R } \\
\text { Square } & \end{array}$ & $\begin{array}{l}\text { Std. Error of } \\
\text { the Estimate }\end{array}$ \\
\hline 1 & $.452^{\mathrm{a}}$ & .034 & .028 & .4224 \\
\hline
\end{tabular}

c.Predictors: (Constant), Participative Leadership Style

d. Dependent Variable: Direction of effort among staff

The Coefficient of determination (Adjusted $\mathrm{R}$ Square) value is .028 indicating that participative leadership style explains $28 \%$ variation in persistence of behavior among staff in private universities in Uganda.

The researcher further carried out a regression Coefficient statistics on participative leadership style and persistence of behavior among staff in private universities in Uganda as presented in Table 9 below.

Table 9: Regression Analysis Coefficient on participative leadership and persistence of behavior among staff in private universities in Uganda

\begin{tabular}{|c|c|c|c|c|c|}
\hline \multirow[b]{2}{*}{ Model } & \multicolumn{2}{|c|}{$\begin{array}{l}\text { Unstandardized } \\
\text { Coefficients }\end{array}$} & \multirow{2}{*}{\begin{tabular}{|l} 
Standardized \\
Coefficients
\end{tabular}} & \multirow[b]{2}{*}{$\mathbf{t}$} & \multirow[b]{2}{*}{ Sig. } \\
\hline & B & Std. Error & & & \\
\hline $\begin{array}{l}\text { 1(Constant) } \\
\text { Participative leadership }\end{array}$ & $\begin{array}{l}2.448 \\
.112\end{array}$ & $\begin{array}{l}.146 \\
.044\end{array}$ & .452 & $\begin{array}{l}16.526 \\
3 . .345\end{array}$ & $\begin{array}{l}.000 \\
.001\end{array}$ \\
\hline
\end{tabular}

b. Dependent Variable: persistence of behavior among staff

Source: Primary Data, 2018

Table 9 indicate a positive and significant effect between participative leadership style and persistence of behavior among staff in private universities in Uganda $(t=16.526$; Sig. $=.000)$. Table 9 further indicate that participative leadership style is a good predictor variable of persistence of behavior among staff in private universities in Uganda $(\beta=.452$; Sig. $=.001)$ implying that for every increase in value of participative leadership style by .452 , persistence of behavior among staff in private universities in Uganda increases by one unit and vice versa. The implication of the above revelation is that participative leadership style significantly affect 


\section{International Journal of Business Management and Economic Review}

Vol. 4, No. 03; 2021

ISSN: 2581-4664

persistence of behavior among staff. Hence, the alternative hypothesis ofthe existence of significant effect between participative leadership style and persistence of behavior among staff in private universities in Uganda is accepted.

\section{DISCUSSION}

Research findings on objective one revealed that majority of the respondents indicated that they are not fully involved in the day to day decision making in the running of the university by the fact that they remained neutral on a number of items that measures their involvement in departmental activities by their $\mathrm{HOD} /$ supervisors. It is therefore evident that they are not involved in decision making, their views and opinion are not taken into consideration and as such they are not in position to take responsibility for decision outcomes where their input is not south. This give a bad impression of leadership style being applied that seem to be more of autocracy than democracy that gives due regard to the concerns and aspirations of all staff at different levels. These are some of the areas that management need to look into if they are to induce staff motivation to work by creating conditions that trigger staff self-direction of their efforts along areas deemed critical without necessarily being pushed.

Findings from hypothesis one testing revealed that participative leadership style has a positive and significant effect on direction of effort among staff.In addition, regression analysis results indicated that participative leadership style is a good predictor variable of direction of effort among staff in private universities in Uganda calling for the need to apply a leadership style that engages staff in the different areas of the organization that affect their work environment so as to direct their efforts accordingly.

Findings from the second objective of the study indicated that participative leadership style enables staff put forth a great deal of effort by exhibiting appropriate behavior that is necessary for task accomplishment and in the process get motivated. This is evidenced by the fact that they persevere during times of hardship at work and that they all work to their best of their ability calling for the need on the part of management to appropriately apply an engagement strategy that would in turn buy their commitment as a sign of motivation.

Research findings further indicated that participative leadership style has a positive and significant effect on staff persistence of behavior among staff in private universities in Uganda. Results from regression analysis further revealed that participative leadership style is a good predictor variable of staff sustaining appropriate behavior and therefore, whenever supervisors apply a participative leader style, staff motivation increases by one unit and the reverse is evident.

\section{CONCLUSIONS}

Participative leadership style has a positive and significant effect on directing staff effort in private universities in Uganda. As a result, supervisors need to always apply a mix of different participative leadership style and enables employees feel motivated and in the process direct their efforts where needed most as a result of being engaged in the day to day running of the organization as opposed to being pushed and threatened. This as a matter of fact induces motivation of staff in the long run.

Relatedly, since participative leadership style was found to be positive and significantly related to persistence of behavior among staff in private universities in Uganda, it is incumbent that 


\section{International Journal of Business Management and Economic Review}

Vol. 4, No. 03; 2021

ISSN: 2581-4664

supervisors create an enabling environment capable of helping staff continue performing and exhibiting behavior deemed necessary to accomplishment of assigned tasks by employees. Thus, the ability of staff to put behave appropriately is an indication of being motivated.

\section{RECOMMENDATIONS}

Management and supervisors of private universities in Uganda should create a work environment where employees are involved in the day to day running of university affairs so that staff feel recognized and appreciated for their worth. This will in turn boost their morale and hence motivation to work. This can be done by consulting with them before an action is taken and above all ensure that their input is put into consideration and not taking them for granted. By so doing, staff will be willing to take responsibility for the outcomes of decisions since they are part and parcel of the decision making process from where they derive feelings of being appreciated and this makes them direct their efforts to required places without necessarily being pushed to work.

In addition, there is need on the part of university management to institute friendly work policies that enable their staff members to continue exhibiting appropriate behavior persistently irrespective of what comes their way. Such policies should be made and implemented in a participative way that allows staff input regarding the formulation and modus operandi. Where staff are involved in policy making they will respect it however pressing they are since they take it as their own brain child that accrued from the contributions. This in turn will make them comply with instructions given by their supervisors.

\section{LIMITATIONS OF THE STUDY}

This study has some potential limitations. It should be noted that a causality effect cannot be inferred due to the cross-sectional nature of the data, although, it is one of the most-used methods in social research (Spector, 1994). Future investigations, should therefore, adopt a longitudinal design so that data can be collected from chosen respondents and participants over a long period of time to establish the reliability of findings. Besides, the data collected for the study were acquired using the questionnaire method that might have led to common method bias and therefore, could have inflated the effect among the variables investigated. For this reason, other data collection methods such as Focus Group Discussions and Interview methods that could have picked individual and group opinions and record attitudes should be used by other researchers. In addition, other leadership styles such as transformational, transactional, and laissez-faire can be explored by other researchers so that all the dynamics surrounding the different contested leadership styles are explored and recorded.

\section{REFERENCES}

Amin, M.E (2005) Social Science Research: Conception, Methodology and Analysis. Kampala, Makerere University Printery.

Armenakis, A. A., Harris, S. G., and Mossholder, K. W. (1993). Creating readiness for organizational change. Human relations, 46(6), 681-703.

Bhargavi, S. \&Yaseen, A., 2016. Leadership Styles and Organizational Performance. Strategic Management Quarterly, 4(1), pp. 87-117.

Cronbach, L. J., and Shavelson, R. J. (2004). My current thoughts on coefficient alpha and 


\section{International Journal of Business Management and Economic Review}

Vol. 4, No. 03; 2021

ISSN: 2581-4664

successor procedures. Educational and Psychological Measurement, 64, 391-218.

Elenkov, D. S., 2002. Effects of leadership on organizational performance in Russian companies. Journal of Business Research, 55(6), pp. 467-480.

Fiedler, F.E. (1967). A Theory of Leadership Effectiveness, New York: McGraw-Hill.

Gaertner S (2000). Structural determinants of job satisfaction and organizational commitment in turnover models. Human. Resource. Management. Review, 9: 479-493.

Harris, A. et al., 2007. Distributed leadership and organizational change: Reviewing the evidence. Journal of Educational Change, 8(4), pp. 337-347.

Heneman, R.L.and Gresham, M.T (1999). The effects of changes in the nature of work on compensation, U.S.A, Ohio state University.

House, R.J. (1971). "A Path Goal Theory of Leader Effectiveness," Administrative Science Quarterly16.Pp. 321-39.

Irannejad P. M. (2008). The management principles (fourth), Second edition: Managers edition.

Kanter R (1999). Managing Change - The Human Dimension. Boston, MA: Good measure.

Khuong, M. N. and Hoang, D. T. (2015). The effects of leadership styles on employee motivation in auditing companies in Ho Chi Minh City, Vietnam, International Journal of Trade, Economics and Finance, Vol. 6, No. 4.

Kirega VPG (2006). Kampala City handbook. Gava Associated Services, Kampala, Uganda.

Koopman, P. L. \&Wierdsma, A. F. M. (1998). Participative management. In P. J.D. Doentu, H. Thierry, and C. J. de-Wolf (Eds.), Personnel psychology: Handbook of work and organizational psychology, 3, pp. 297-324, Hove, UK: Psychology Press.

Mitonga-Monga, J. \& Coetzee, M., 2012. Perceived leadership style and employee participation. African Journal of Business Management, 6(15).

Mullins, L.J. (2005). Management and Organizational Behavior. ( $7^{\text {th }}$ Edidtion). Prentice Hall.

Nemaei, B. (2012). The Impact of participative leadership on employee's motivation, job satisfaction and innovation. The British University in Dubai (BUiD).

Scully, S; Kirkpatrick, A, and Locke, E.A. (1995). Locus of Knowledge as a Determinant of the Effects of Participation on Performance, Affect, and Perceptions.Organizational Behavior and Human Decision Processes, vol. 61, issue 3, 276-288.

Somech, A. (2002). "Explicating the complexity of participative management: an investigation of multiple dimensions," Journal of Educational Administration Quarterly, vol. 38, pp. 341-371.

Tannenbaum, R., and Schmidt, W. H. (2012). How to choose a leadership pattern. Los Angeles, CA: University of California.

Tomaskovic-Devey, D; Leiter, J; and Thompson, S. (1994). Organizational Survey non response. Administrative science quarterly, 39, 439-457.

Wu, T.F. (2006). A Study of the relationship between manager's leadership Style and Organizational Commitment in Taiwan's International Tourist Hotels. Asian Journal of management and Humanity, vol. 1, No.3, pp. 434-452.

Xu, G. Y. and Wang, Z. S. (2008). The impact of transformational leadership style on organizational performance: The intermediary effects of leader-member exchange. CA, USA: Long Beach. 
International Journal of Business Management and Economic Review

Vol. 4, No. 03; 2021

ISSN: 2581-4664

Yammarino, F. J. \&Naughton, T. J. (1992). Individualized and group-based views of participation in decision making. Group and Organization Management, (17) 398-413.

Yukl, G. (2002). Leadership in Organizations, 5th ed. Prentice-Hall Inc.

Zeffane, R. (2003). Patterns of Organizational Commitment and Perceived Management Style: A Comparison of Public and Private Sector Employees. Human. Relations, 47(8): 9771010. 